\title{
Coconut Sugar Quality Control Analysis of Home-Industry in Central Java
}

\author{
Wiwi Susanti ${ }^{1}$, Diah Rina Kamardiani ${ }^{1,{ }^{*}}$, Ikhsan Adi Pratama $^{1}$, Qholiva Yuni Fadilla $^{2}$ \\ ${ }^{1}$ Department of Agribusiness, Faculty of Agriculture, Universitas Muhammadiyah Yogyakarta, \\ Indonesia \\ ${ }^{2}$ Media and Cultural Studies, Universitas Gadjah Mada, Indonesia
}

\begin{abstract}
Coconut sugar is a potential trade commodity, and Indonesia is one of the biggest exporters in the world. There were some problems such as the use of raw material was not optimum and some quality issues. The study aims to identify the defective product and evaluate the current process capacity at Ngudi Lestari as one of the biggest home-industry in Central Java. The method was use the Six Sigma Method through DMAIC tools. The data was used primary data from 28 times production during seven days through the observation process. The finding showed that there were nine potential critical to quality that affects sugar. The control chart showed that production in Ngudi Lestari still uncontrollable. It was indicated by the process that out of control limit was about $75 \%$. The result of the sigma value was sufficient, which was 4.39. It had reached the average sigma level of industry in the United States. The defective products were caused by raw materials, labor, equipment, and production process. The raw material was one factor that had a significant effect on the quality of coconut sugar.
\end{abstract}

\section{Introduction}

Coconut sugar is a potential trade commodity in the world. Indonesia is one of the biggest exporters of coconut sugar besides Thailand and Philippines, so this product has considerable potential to develop in Indonesia [1,2]. Coconut sugar is mostly produced by Small Micro Medium Enterprises (SMEs). SMEs are one of the main contributors to the economic growth in Indonesia [3]. Coconut sugar is becoming popular as an alternative to beetroot or cane sugar because it has a low glycemic index and high mineral content, which makes it attractive to many people compared to conventional sugar [4].

Production of coconut sugar in Indonesia in 2012 was 14,095 tons with an export value of USD 18,402 million and rising to 25,578 tons in 2018 with an export value of USD 52,521 million [1]. The biggest destination country to export coconut sugar is the United States, followed by China, Netherland, Germany, and Malaysia. The value export of the United States was reaching USD 845.5 million. The rising export volume and value become an opportunity for Indonesia to produce coconut sugar [5].

\footnotetext{
* Corresponding author: kamardiani@umy.ac.id
} 
The great opportunity for coconut sugar demand is still not supported by nira as an optimum raw material [5]. On the other hand, quality also becomes one of the critical issues that often occur in Indonesia. Banyumas, as a region with high production of coconut sugar in Central Java [6], also has quality problems. The several quality problems that were frequently found were the unstandardized product, mixed with chemical material (Natrium bisulfite), and mixed by strange material such as gaplek and rice [7]. This condition influences the marketing processes, mainly export. Export of product should be passed some criteria that were requested by the destination country.

In Banyumas, there was a home-industry of coconut sugar that succeeded in exporting coconut sugar. Ngudi Lestari is one of the biggest producers of coconut sugar which exports its product to Singapore, Saudi Arabia, and the United States, besides the local market since 2000. Although Ngudi Lestari has been exporting for a long time, but there was found some quality problems. The problems were wet sugar, inappropriate colors, inappropriate shapes, and mixed by the strange material. In this aspect, the quality control process of coconut sugar production in Ngudi Lestari was interesting to study due to reducing the defective product by knowing the main causes.

Several previous studies have shown that various factors cause the quality problem. The unavailability of the operator, programming the machine, and tool exchange influenced the Mould Industry. By using Six Sigma, it will be obtained an improvement of about 20\% [8]. The other research showed that the quality of the extraction process is mostly influenced by feeding failure, lumps, risk, length dimensions, and receipt parameters. Six Sigma was used to decrease the $0.89 \%$ work-off generated by the production system [9]. The research about wire rod production showed that bearing roll has the highest weight of 0.94569 and has become the priority that should be fixed. The sigma value was 4.297503 with DPMO 2,928.626 [10]. Six sigma approaches using the DMAIC cycle were also used to find the significant factors that affect the $\mathrm{pH}$ of yogurt. The results showed that incubation time and fat percentage were the significant factors on the $\mathrm{pH}$ value of yogurt [11].

The previous studies were provided an overview of the using the Six Sigma approaches mostly in the non-consumption product. This research looked at the using Six Sigma approaches in consumption products as an essential necessity. Using Six Sigma method, this study aims to evaluate the current condition and process capability by knowing the defect value of coconut sugar production. Define, Measure, Analyze, Improve, and Control (DMAIC) tools were used to improve quality characteristics [11].

\section{Research Method}

This study used the descriptive method and quantitative approach to describe the findings. The study was conducted at Ngudi Lestari as one of the biggest producer of Coconut sugar in Central Java and has a production capacity of 1.6 tons per day. The primary data was collected through observation of coconut sugar production. The amounts of data were 28 productions times during seven days from two woks and were done two times per day per wok. The quantitative method was analyzed using the six sigma methods. Six sigma is one of the quality control methods used in statistical analytics. Six sigma approach consists of 5 cycles that are defined, measure, analyze, improve and control or usually called DMAIC, and used to quality improvement strategy $[9,12]$.

Define was used to define the existing problems, determine the action planning and determine the goals. The measure was used to measure sigma level and the defect per million opportunities (DPMO). Analyze was used to analyze the causes of defect product used Pareto chart and cause and effect chart (fishbone chart). Improve was used to improve each existed problem. Control was used to look after the value or improvement that should 
be done to improve the quality product. The measurement process in Six Sigma will follow some equations.

The proportion of defect products will be following Equation 1:

$$
\mathrm{p}=\frac{\sum \mathrm{n}_{\mathrm{p}}}{\sum \mathrm{n}}
$$

where, $\mathrm{p}$ was the proportion of defect product, $n_{p}$ was the amount of defect product, and $\mathrm{n}$ were the amount of sample.

Upper Control Limit, Lower Control Limit and Center Line was measured used Equation 2, 3 and 4 [13].

$$
\begin{aligned}
& \mathrm{UCL}=\mathrm{p}+1,5 \sqrt{\frac{\mathrm{p}(1-\mathrm{p})}{\mathrm{n}}} \\
& \mathrm{LCL}=\mathrm{p}-1,5 \sqrt{\frac{\mathrm{p}(1-\mathrm{p})}{\mathrm{n}}} \\
& \mathrm{CL}=\mathrm{p}
\end{aligned}
$$

where, UCL was Upper Control Limit, LCL was Lower Control Limit, CL was Control Line, p was amount of defect product and $\mathrm{n}$ was the amount of sample.

Sigma level and Defect per Million Opportunities (DPMO) was analyzed following the steps in Table 1.

Table 1. The Steps of Sigma Value Analysis

\begin{tabular}{|c|l|c|}
\hline Steps & \multicolumn{1}{|c|}{ Action } & Remark \\
\hline 1 & The kind of process that would be known & - \\
\hline 2 & How many the unit is produced & - \\
\hline 3 & How many the defective product & Step 3/Step 4 \\
\hline 4 & Counting the level of defect based on step 3 & Amount of CTQ \\
\hline 5 & $\begin{array}{l}\text { Determine the Characteristics of Quality (CTQ) the amount } \\
\text { of defect product }\end{array}$ & Steps 4/Step 5 \\
\hline 6 & Counting the proportion defect based on CTQ & Step 6 x 6,000,000 \\
\hline 7 & Counting the DPMO & - \\
\hline 8 & Conversion of the value of DPMO to Six Sigma & \\
\hline
\end{tabular}

Source: [14]

\section{Results and Discussion}

\subsection{Amount of Defective Product}

The defective product was a disorder of product that was inappropriate with the standard of quality. The quality characteristics were measured based on the shape, color, size, cleanliness, and texture (soft/wet). It was slightly different from the Indonesian National Standard (SNI) No. 01-3743-1995 about Palm Sugar. The requirement characteristics of quality by SNI can be seen in Table 2 .

The defect was measured based on the characteristics of quality at Ngudi Lestari and the average of a defective product are shown in Table 3. 
Table 2. Palm sugar quality requirements based on SNI 01-3743-1995

\begin{tabular}{|c|c|c|c|c|}
\hline \multirow[t]{2}{*}{ No. } & \multirow[t]{2}{*}{ Criteria } & \multirow[t]{2}{*}{ Unit } & \multicolumn{2}{|c|}{ Requirement } \\
\hline & & & Form & Granules \\
\hline \multirow[t]{4}{*}{1.} & Condition & & & \\
\hline & Shape & & Normal & Normal \\
\hline & Taste and aroma & & Normal, distinct & Normal, distinct \\
\hline & Color & & Tawny or brown & Tawny or brown \\
\hline 2. & Insoluble parts & $\% \mathrm{~b} / \mathrm{b}$ & Max. 1.0 & Max. 0.2 \\
\hline 3. & Water & $\% \mathrm{~b} / \mathrm{b}$ & Max. 10.0 & Max. 3.0 \\
\hline 4. & Ash & $\% \mathrm{~b} / \mathrm{b}$ & Max. 2.0 & Max. 2.0 \\
\hline 5. & Reducer sugar & $\% \mathrm{~b} / \mathrm{b}$ & Max. 10.0 & Min. 6.0 \\
\hline 6. & Sugar as saccharose & $\% \mathrm{~b} / \mathrm{b}$ & Max. 77 & Min. 90.0 \\
\hline \multirow[t]{3}{*}{7.} & Metal contamination & & & \\
\hline & Zink $(\mathrm{Zn})$ & $\mathrm{Mg} / \mathrm{kg}$ & Max. 40.0 & Max. 40.0 \\
\hline & Plumbum $(\mathrm{Pb})$ & $\mathrm{Mg} / \mathrm{kg}$ & Max. 2.0 & Max. 2.0 \\
\hline
\end{tabular}

Source: [15]

Tabel 3. Average of Defective Coconut Sugar Product in Ngudi Lestari

\begin{tabular}{|l|r|r|r|}
\hline \multicolumn{1}{|c|}{ Size } & Total Production (piece) & Defect (piece) & $\begin{array}{c}\text { The proportion of defects } \\
(\%)\end{array}$ \\
\hline BL (100 gr) & 2,195 & 42 & 1.90 \\
\hline Flat (100 gr) & 2,898 & 63 & 2.16 \\
\hline Coin $(50 \mathrm{gr})$ & 4,618 & 53 & 1.15 \\
\hline Jumbo $(250 \mathrm{gr})$ & 804 & 24 & 3.04 \\
\hline
\end{tabular}

Based on Table 3, two products have the same weight, which was BL and Flat. The difference between these two sizes was in the mold; BL has a narrower diameter but higher than flat. Table 3 also shows the highest proportion of defects was occurring in jumbo at $3.04 \%$; this occurs because the jumbo size needs a longer cooling time than other sizes. Fulfillment of target and limitations of the mold causes the cooling process to be less than optimal and nonconforming. Hence, it causes the color of coconut sugar to become white patches and not in conformity with the standards. It was in line with [16] that conforming cooling in the forms for injection molding of plastic has a positive effect on shortening the production cycle and improving the product's dimensional stability. The smallest proportion of defects occurs in coins with a percentage of $1.15 \%$; this occurs because the cooling process was faster and optimum. Another suspected factor that caused the defect was more significant in jumbo because the product was more marketed in the domestic market than other sizes. It causes the quality control not optimum.

\subsection{Analysis of Quality Control using Six Sigma Method}

Six Sigma is used to repair, maintain and improve the production capabilities of a business unit to realize the zero defects principle. The six sigma quality control method used in this study was carried out through five cycles: Define, Measure, Analyze, Improve, and Control (DMAIC). This approach provided the necessary support to the organization to produce products more quickly and economically with more excellent quality [6].

\subsubsection{Define}

Define was used to define the problem that causes product defects in coconut sugar production. The pre-survey found five critical of the quality of defective products: color, size, shape, cleanliness of sugar, and texture (soft or wet). Different from the pre-survey, 
the observation process found nine critical of the quality of defective products that can be defined as:

a. Color: defects in this criterion were dominated by white patches on coconut sugar that caused the color of sugar out of standard. In addition, some sugars have a rather dull color.

a. Shape: the defect was mostly caused by the presence of the chipped part or perforated. Hence, the coconut sugar was not intact, and the surface was too concave. The dented sugar mold also caused the shape of sugar did not fit the criteria.

b. Size: the most frequent defect was caused by the lack of volume when the dough was poured into the mold, so the sugar was underweight and thin.

c. Cleanliness of sugar: the most dominant cause of defects was mixed by strange objects such as small pieces of wood, coconut flowers, or insects. This condition often occurs because the filter is filthy.

d. Texture (soft or wet): wetly and soft sugar become the main problem of defect criteria on texture.

e. Shape and Texture: this product defect was dominated by chipped or dented shapes combined with wet or soft sugar.

f. Shape and Size: the main cause of this defect is the combination of inappropriate sugar shapes and under standard size, hence cannot fulfill the consumer's requirement.

g. Color and Size: this defect was caused by the coconut sugar with white patches and under standard size.

h. Color and Shape: this defect was caused by coconut sugar with white patches and an inappropriate shape.

\subsubsection{Measure}

Measure divided into two steps; the first step was analysis using the control chart, and the second was an analysis of sigma level based on the conversion of Defect per Million Opportunities (DPMO) values.

\section{a. The Analysis of The Control Chart}

$P$ chart analysis was used because the data was varied in each observation period and used the proportion of the defective product. This analysis was conducted using data of 28 times production processes at Ngudi Lestari within seven days. P control chart obtained on coconut sugar production in Ngudi Lestari was as at Figure 1.

$P$ chart in Figure 1 shows that coconut sugar production in Ngudi Lestari based on the overall average was still uncontrolled. This state showed through the amount of data that exceeds the upper control limit was approximately $39.29 \%$, and data that exceeds the lower control limit was approximately $35.71 \%$. It was following research about tea quality that was also still uncontrolled. It was demonstrated by the existence of out-of-control data that exceeded the control limit on the P chart. [17].

The highest proportion of defects occurs in process 11 , which produces a considerable number of defective products in a small number of productions. Small production occurs due to the sugar was made in jumbo. The most common mistake in this process was the color caused by the lack of raw material quality from both nira and local coconut sugar as additional material. Almost 50 percent of local sugar used was wet and softy, which affects the sugar produced. It was in line with the research of [18] that cookies produced using low-gluten flour have a better texture than cookies produced using high-gluten flour. It means that raw materials affect the quality of the product. 


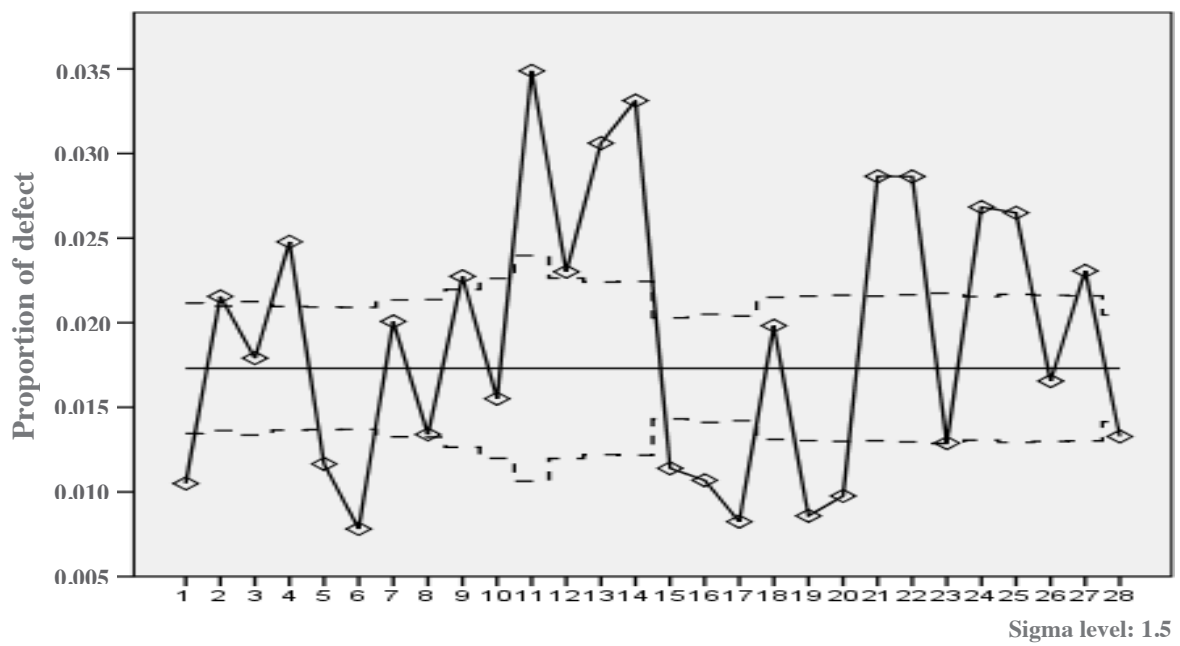

Fig. 1. P control chart of coconut sugar production in Ngudi Lestari

Information:

$\begin{array}{ll}------ & : \text { Upper control limit and lower control limit } \\ & : \text { Centerline } \\ & : \text { Proportion of defects }\end{array}$

\section{b. Sigma Level Measurement based on the DPMO conversion}

Based on Defect per Million Opportunities (DPMO) calculation using Motorola's 6-sigma process, production in Ngudi Lestari had process capability at sigma level 4.39. This sigma value means that every one million times production will be about 1,926 possible defective coconut sugars. It showed that the process capability was sufficient. The research of [10] also shows that the capability process in sigma level 4 is sufficient because it has reached the industry average of the United States (approximately 4 sigma). Although, the sigma level was sufficient, Ngudi Lestari must continue to make improvements to improve the process capability to realize zero defects. The higher the sigma value will indicate the better quality of an industry or company. Raising the sigma level from 4 to 5 requires approximately 30 times of improvement, and raising the sigma level from 5 to 6 requires approximately 70 times. It means that increasing sigma level from 4 to 6 requires approximately 2,100 processes of improvements [13].

\subsubsection{Analyze}

Analysis was used to find out the most dominant defect characteristics and what needs to be controlled. The tools used were Pareto Chart and Fishbone Chart. A fishbone chart was used to analyze the root factors that cause defective products.

\section{a. Pareto Chart}

Pareto Chart was used to show the degree of defects from the highest to the lowest. This chart will be helpful for companies to prioritize improving existing problems. The data used in the Pareto chart was the percentage data per characteristic defect. Figure 2 shows the results of an analysis of the Pareto Chart obtained from the average defective product.

Based on Figure 2, the highest dominant defective of coconut sugar production was out of standard color (more than $40 \%$ ). It causes because the raw material was still varied and less controllable, affecting the unstable color of sugar. The high moisture content and $\mathrm{pH}$ of 
nira will affect the formation of coconut sugar color due to enzymatic reaction in processing [19]. This circumstance indicates that the color issue must be a priority to control.

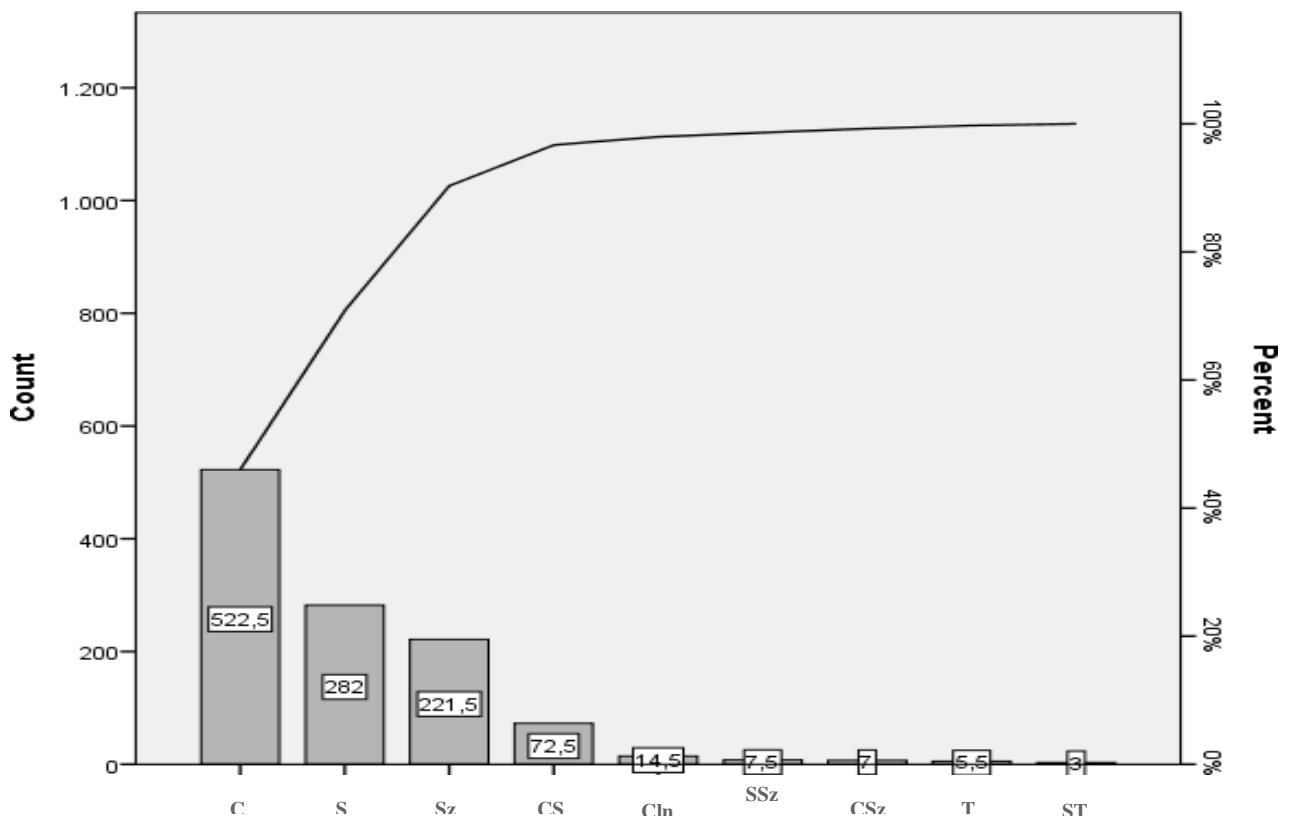

Fig. 2. Pareto Chart of the coconut sugar production process in Ngudi Lestari

where, $\mathrm{C}$ was color, $\mathrm{S}$ was shape, Sz was the size, CS was color and shape, Cln was the cleanliness of sugar, SSz was shape and size, Csz was color and size, T was texture, and ST was shape and texture.

b. Fishbone Chart

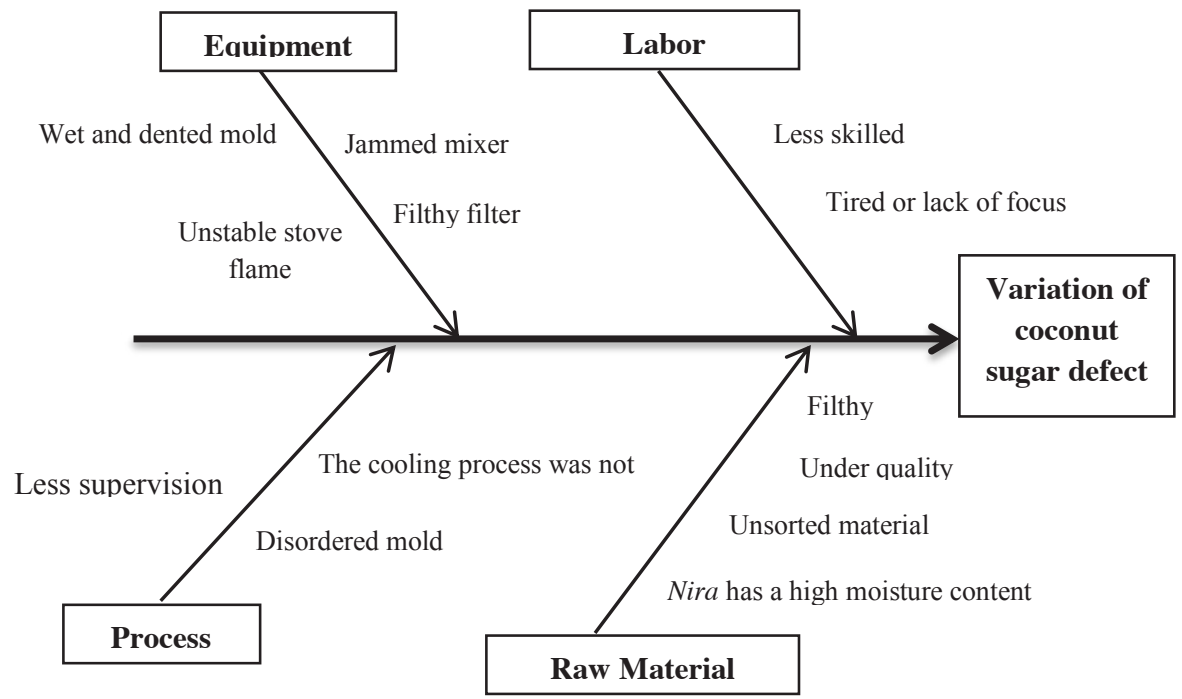

Fig. 3. Causal chart (Fishbone Chart) of defective product variations in coconut sugar production 
Fishbone charts in Figure 4 were used to analyze the causative factors of the defect. The control chart of the production process shows the variety of defective products that were high enough and needed to be controlled. The control process can be taken if the causative factor is identified. Based on the observations and interviews, the main factors that caused the variation of defective products were labor, equipment, processes, and raw materials. The analysis of the causal diagram on quality control of rice seeds product showed the cause of damage in rice seed production process is human, work environment, method and machine [20]. The result of [21] also supports that workers/operators, production equipment, and production processes have the highest importance in influencing product quality in the milk processing industry.

\subsubsection{Improve}

Improvement was used to create a plan to increase the sigma level. Based on the cause of the defect, a recommended action can be taken to increase the capabilities of the process in Ngudi Lestari as follows:

\section{a. Labor}

Labor is a factor that affects the coconut sugar quality; it can occur when humans are not sufficiently competitive, motivated, and skilled in their work [22]. Recommendations for actions that can be taken to overcome this problem were to provide work motivation, training, guidance, and mentoring to less skilled employees. The improvement of professional training and motivation of employees also was most fully implemented in enterprises belonging to the territorial innovation clusters [23]. Other actions that can be taken are evaluating periodically and imposing a reward and punishment system to encourage employee performance to be more optimal.

\section{b. Equipment}

The production equipment such as wet mold, unstable stove flames, jammed mixers, and filthy filters can affect the quality of coconut sugar. Actions that can be taken to fix the problems are monitoring the drying process and increasing the number of molds accommodated to the demand. Unstable stoves flames must be overcome by checking the flow of fuel and repair of stove lighters. Causative factors such as jammed mixers can be controlled by maintaining, checking, and changing lubricants periodically and ensuring the electrical power used. Maintenance for the machine is one of the actions to fix equipment problems [24]. Another action is to clean the filter and give attention to the filter storage area; it can reduce defective products caused by filthy filters.

\section{c. Raw Material}

Nira and local coconut sugar as raw materials should be sort before being used to produce the sugar. The $\mathrm{pH}$ value of nira will affect the color, and the water content will affect the texture of sugar [25]. The sortation could reduce the entrance of under quality raw material such as nira with high moisture content. Actions that can be taken to reduce the defect based on this factor are approaching raw materials by looking for information on areas with good raw material quality. Improving the quality of nira in the rainy season can also be taken by guiding how the farmers extract nira in the rainy season. Maintaining the cleanliness of the work environment could be taken to ensure raw materials are clean.

\section{d. Processes}

The observations showed that the other factor of the defective product was the process step. Actions that can be taken to overcome this include providing standard operating procedures 
(SOP) and providing direction and supervision to employees. The designing of SOP based on critical control point (CCP) also can reduce hazards in the production process [26]. Another action that can be done to overcome the cooling process is noting the optimum cooling time for every size of coconut sugar. Making the process run optimally and reducing the number of defective products can also be done by checking the condition of equipment and all supporting materials.

\subsubsection{Control}

The control step was the last step in six sigma using DMAIC cycle. The action used to ensure the improvement step in coconut sugar production was maintained. This step requires supervisory steps in each process and results and corrective actions for more stable performance. Improvements of product and process quality and reliability must be implemented in all product life cycle phases beginning from the product concept formulation, validation, full-scale development, maintenance, production and use, because they lead to product value enhance and lower manufacturing costs, and the qualitative product does not need to be repaired and do not delay in the delivery [20]. The implementation of the control stage consists of three components as follows:

\section{a. Standards and objectives}

Establishing standards and objectives that must be achieved based on the standard characteristics of the requested product. This state can be done by setting the targets in each step of production, such as receiving raw materials to the production process to full fill the standards of quality, and the study found the long-term planning and organizational culture had a very significant impact on product quality [27]. Based on observations and interviews process, Ngudi Lestari has implemented to set the standard of the product.

b. Ways to measure the successes

Measurement of success is information that shows whether the repair process has been achieved. This state can be taken by managers and employees at Ngudi Lestari. This way ensures that raw materials, equipment, and all necessary components are following the established standards. Ngudi Lestari has been monitoring the use of a combination of raw materials and equipment conditions but has not been intensive.

c. Comparison between actual results and standards

This step can be taken by comparing the monitoring results with the standards set and using the $\mathrm{P}$ chart to monitor production results. This step must be able to be done by all elements located in the Ngudi Lestari so the improvement process can do continuously.

\section{Conclusions}

The findings showed that the average of defective products found in Ngudi Lestari for BL size as much as $1.90 \%$, flat $2.16 \%$, coins $1.15 \%$, and jumbo $3.04 \%$ of the total sugar produced. The results of the six sigma analysis at the define found nine critical of quality such as color, shape, size, cleanliness of sugar, texture (soft or wet), shape and texture, shape and size, color and size, and color and shape. The $\mathrm{P}$ chart showed that exceeds products of the upper and lower control limits is approximately $75 \%$. The sigma value obtained was at 4.39 . It means that every one million times production will be about 1,926 possible defective coconut sugars. The most dominant defect characteristic was color, and the smallest was the combination of shape and texture. Factors that caused the quality of defective products were labor, equipment, raw materials, and production processes. 


\section{References}

1. Media Perkebunan, Indonesia, Eksportir Utama Gula Kelapa, (2020).

2. Suliyanto, W. Novandari, and Suwaryo, The influence of market orientation on marketing performances in micro small and medium-sized (MSMEs) coconut sugar enterprises: The role of innovation, Qual. - Access to Success 20, 143 (2019).

3. P. Nia Budi, Y. Muhammad Faisal Afa, and R. Zainal Fanani, Green Manufacturing Challenge in Small and Medium Industries (SMEs) Batik Laweyan Surakarta, E3S Web Conf. 202, 1 (2020).

4. T. Buddhi Satyarini, Sutrisno, and F. Wira Kartika, Feasibility Based on Production Patterns by Home Industries in Hargotirto, Kokap, Kulon Progo, Yogyakarta, E3S Web Conf. 232, (2021).

5. 4. B. Seruni, Warta Ekspor: Produk Olahan Kelapa," Direktorat Jenderal Pengambangan Ekspor Indonesia, Kementerian Perdagangan, (2020).

6. 5. S. Sudarto, A. Suroso, and D. P. Jati, Potential and Problems of Small Medium Enterprise (SMEs) Coconut-Sugar: Case Study in Banyumas Regency, Central Java Indonesia, Int. J. Bus. Manag. 8, 18 (2013).

7. 6. Pemerintah Kabupaten Banyumas, Laporan Kinerja Instansi Pemerintah Tahun 2016 Kabupaten Banyumas (2016).

8. 7. A. M. H. Pereira, M. R. Silva, M. A. G. Domingues, and J. C. Sá, Lean six sigma approach to improve the production process in the mould industry: A case study, Qual. Innov. Prosper. 23, 103 (2019).

9. 8. T. Costa, F. J. G. Silva, and L. Pinto Ferreira, Improve the extrusion process in tire production using Six Sigma methodology, Procedia Manuf. 13, 1104 (2017).

10. M. Ulfah, R. Ekawati, and N. Amalia, Minimize the potential failures in the wire rod production process using six sigma and multi attribute failure mode analysis method, IOP Conf. Ser. Mater. Sci. Eng. 909, (2020).

11. S. Hakimi, S. M. Zahraee, and J. Mohd Rohani, Application of Six Sigma DMAIC methodology in plain yogurt production process, Int. J. Lean Six Sigma 9, 562 (2018).

12. O. Syafwiratama, M. Hamsal, and H. H. Purba, Reducing the nonconforming products by using the six sigma method: A case study of a polyester short cut fiber manufacturing in Indonesia, Manag. Sci. Lett. 7, 153 (2017).

13. V. Gaspesz, Metode Analisis Untuk Peningkatan Kualitas (Gramedia Pustaka Utama, Jakarta, (2003).

14. A. Muhaemin, Analisis Pengendalian Kualitas Produk Dengan Metode Six Sigma Pada Harian Tribun Timur, Universitas Hasanuddin, (2012).

15. Badan Standardisasi Nasional, Syarat mutu gula palma berdasarkan SNI 01-37431995, (1995).

16. E. Vojnová, The benefits of a conforming cooling systems the molds in injection moulding process," Procedia Engineering, Procedia Eng. 149, 535 (2016).

17. W. Sulistiyowati, D. T. Handoko, and H. Catur Wahyuni, Implementation of Statistical Process Control Method and Root Cause Analysis on Quality of Bitter Tannin Tea Tin, IOP Conf. Ser. Earth Environ. Sci. 519, (2020).

18. J. Zhang, Y. Y. Zhao, X. D. Li, and J. H. Rong, Effect of Raw Material Properties on Cookie Quality and Acrylamide Generation, Mod. Food Sci. Technol. 36, (2020).

19. E. Nurlela, Kajian Faktor-Faktor Yang Mempengaruhi Pembentukan Warna Gula Merah, IPB University, 2002. 
20. Y. R. Ramadan, E. Bambang, E. Desia, and I. Fadah, Analysis of quality control of rice seed products with the introduction of sqc model (Statistical quality control) at ud. mayang srie-mayang jember district), Int. J. Sci. Technol. Res. 7, 199 (2018).

21. M. Dachyar and G. P. Rachmadhani, Factors influencing product quality in milk processing industry," Proceedings of the International Conference on Industrial Engineering and Operations Management, Proc. Int. Conf. Ind. Eng. Oper. Manag. 98 (2019).

22. A. Bargelis, D. Čikotiene, and Z. Ramonas, Impact of human factors and errors for product quality and reliability in the integrated approach of product and process design, maintenance and production, Mechanika 20, 92 (2014).

23. L. A. Kostygova and L. A. Kostygova, Improving the system of indicators of labor resources use, measures to improve the skills and motivation of employees in the digital economy (on the example of the titanium territorial innovation cluster), ACM Int. Conf. Proceeding Ser. (2020).

24. O. Nooted and S. Tangjitsitcharoen, Defective Reduction in Frozen Pie Manufacturing Process, IOP Conf. Ser. Mater. Sci. Eng. 215, (2017).

25. M. D. Erwinda and W. H. Susanto, Pengaruh pH Nira Tebu (Saccharum officinarum) dan Konsentrasi Penambahan Kapur Terhadap Kualitas Gula Merah, J. Pangan Dan Agroindustri 2, 54 (2014).

26. N. T. Putri, A. Rhamadani, and W. Wisnel, Designing food safety standards in beef jerky production process with the application of hazard analysis critical control point (HACCP), Nutr. Food Sci. 50, 333 (2020).

27. R. Lombard, C. C. Van Waveren, and K. Y. Chan, Factors affecting quality in a manufacturing environment for a non-repairable product, in IEEE Int. Conf. Ind. Eng. Eng. Manag. (2014), pp. 137-142. 